Article

\title{
Female Directors and Corporate Social Responsibility: Evidence from the Environmental Investment of Chinese Listed Companies
}

\author{
Feng Wei ${ }^{1, *}$, Binyan Ding ${ }^{1}$ and Yu Kong ${ }^{2}$ \\ 1 School of Economics and Business Administration, Chongqing University, Chongqing 400-044, China; \\ 201702021009@cqu.edu.cn \\ 2 School of Public Affairs, Chongqing University, Chongqing 400-044, China; kongyu@cqu.edu.cn \\ * Correspondence: wfmx@cqu.edu.cn
}

Received: 16 November 2017; Accepted: 6 December 2017; Published: 13 December 2017

\begin{abstract}
Taking Chinese listed companies in 2008-2015 as the sample, in this paper we test in detail the impact of female directors on corporate environmental investments. Furthermore, we study the impact of female directors on environmental investment in enterprises with different types of ownership and industry attributes. Empirical studies show that when there are only 1 or 2 female directors on the board, no significant impact on the scale of corporate environmental investment can be seen. However, when the number reaches at least 3 , female directors have a significantly positive impact on the scale of corporate environmental investment. This confirms critical-mass theory; meanwhile, we find that the empirical results do not indicate any significant correlation when the variable of female directors is measured by the proportion of female directors and the Blau index of gender balance. Further analysis suggests that in state-owned enterprises and enterprises from heavily-polluting industries, the above findings remain true, while in non-state-owned enterprises and enterprises from non-heavily-polluting industries, the above findings prove false, i.e., that the impact of female directors on corporate environmental investment is not significant. The conclusion demonstrates that the impact of female directors on environmental investment varies in enterprises with different types of ownership and industry attributes.
\end{abstract}

Keywords: female directors; environmental investment; critical-mass

\section{Introduction}

Since the reform and opening up, great progress has been made in both social and economic development in China for more than 30 years, but the ensuing environmental problems have become increasingly serious. The World Bank's study (2001) shows that China occupies 16 of the 20 most polluted cities in the world and is the world's largest emitter of sulfur dioxide $\left(\mathrm{SO}_{2}\right)$ and carbon dioxide $\left(\mathrm{CO}_{2}\right)$ [1]; environmental pollution causes about 3.5-8\% loss in the GDP each year [2]. In 2016, the air quality of 84 cities in 338 prefecture-level and above cities was up to standard, accounting for $24.9 \%$, while $75.1 \%$ of cities are still not up to standard (The 2016 National Air Quality Status released by the Ministry of Environmental Protection on January 23, 2017). According to statistics, more than $80 \%$ of environmental pollutants (wastewater, waste gas, etc.) are produced in enterprises and enterprises have become resource and energy consumers and environmental pollution producers [3]. On 18 October 2017, Chairman Xi Jinping put forward that "There is still a long way to go in protecting the ecological environment" at the 19th National Congress of the Communist Party of China, and pointed out that great efforts should be made to solve the outstanding environmental problems, indicating that we should establish an environmental governance system in which the government gives the direction, enterprises work as the main body, and social organizations and the 
public are widely involved. As the main body of economic operation, enterprises on the one hand gain productive resources from the environment, and on the other hand generate emissions to the environment, which is an important cause of environmental pollution, so enterprises should fulfill the responsibility of environmental protection in the pursuit of economic efficiency. In response, relevant government departments have paid great attention. On 14 September 2010, Ministry of Environmental Protection released the Guide for Environmental Information Disclosure of Listed companies, which for the first time specifically requires listed companies to issue environmental reports on a regular basis. Meanwhile, the Ministry of Environmental Protection urged enterprises to strengthen their supervision over the discharge of pollutants during production and operation, and disclose relevant information to the public and government departments. In 2011, excessive blood lead levels were found in hundreds of children, along with the disclosure of the long-term violation of emissions by Harbin Pharmaceutical Group Pharmaceutical Factory, which once again drew great attention of the government and the public on the environmental problems. In November 2013, the decision of the Central Committee of the Communist Party of China on some major issues concerning comprehensively deepening the reform was adopted at the Third Plenary Session of the 18th Central Committee of the Communist Party of China, calling for the establishment of a sound ecological environmental protection system in order to regulate the environmental protection behaviors systematically. The implementation of these policies promotes enterprises to raise awareness of environmental protection and strengthen environmental governance.

In order to fulfill environmental protection obligations and undertake social responsibilities, enterprises need to continuously invest capital, purchase facilities and develop advanced technologies [4]. The motivation of enterprises to actively undertake social responsibility and carry out environmental investment activities is obvious. Having good corporate social responsibility helps to improve corporate transparency and reduce the information asymmetry between business and stakeholders [5] and to improve long-term corporate value [6]. According to the quaternity indicator system in Research Report on Corporate Social Responsibility of China, social responsibility includes four aspects: management responsibility, market responsibility, public welfare responsibility and environmental responsibility. This paper mainly studies the corporate social responsibility from environmental investment perspective. In addition to the government's policies, corporate environmental investment is affected by many other factors. Through reviewing previous academic achievements, we find the following factors affecting corporate environmental investment: External factors, mainly including government regulation [7], economic development and legislation [8], and internal factors, including board structure [9], management behavior [10] and ownership structure [11]. At present, there are not many researches on internal factors in China, because many researches pay more attention to external factors [7,12]. This results in a lack of basis for guiding the corporate environmental investment. Therefore, in this paper we focus on internal factors in order to study the impact of female directors on corporate environmental investment.

Many countries pay more and more attention to the gender composition of the board of directors. In February 2002, the Norwegian government promulgated a legislative proposal aiming at achieving $40 \%$ of female directors on the board, which officially entered into force in 2005 [13]. Subsequently, other countries successively enacted quota laws and clearly stipulated related sanctions laws such as Finland, Iceland, Italy and France. In addition, many countries proposed that the qualified corporate governance structure should consider the gender composition of the board of directors, which include Denmark, Germany, Ireland and so on [14]. In China, with the improvement of the female status and their comprehensive quality, an increasing number of female directors emerged, who have become the indispensable and key factor in corporate governance [15]. The research on director gender has been extended to many aspects of corporate governance in the academic world. From many aspects, the role of female directors in board decision-making was studied, such as charity expenditure [16-18], corporate innovation [13], and corporate performance [19-21]. It can be found from the previous literature that female directors can influence the board of directors in some aspects 
of decision-making, but the impact of female directors on corporate environmental investment has not been studied at home and abroad. However, there is more research on corporate social responsibility related to corporate environmental investment. Based on a sample of more than 500 listed companies in the United States, Zhang et al. [22] found that a higher proportion of female directors will result in a higher performance level of corporate social responsibility. Having reviewed the literature on the relationship between board diversity and corporate social responsibility, Rao and Tilt [23] highlight the importance of linking the gender diversity on the board to the decision-making process of corporate social responsibility. Hyun et al. [6] considered the inherent mechanism of female directors and obtained positive correlation between the number of female independent directors and corporate social responsibility, which is a further promotion of prio studies. Taking the sample of 91 listed companies in France in 2001-2011, Nekhili et al. [24] find that board diversity has an impact on corporate social responsibility. Through researching, Jizi [25] finds that the participation of female directors on the board is conducive to improving corporate social responsibility and developing ethical policies. The dimensions of social responsibility are relatively broad. Environmental investment is the environmental responsibility of enterprises in fulfilling their social responsibility, but the research on the direct impact of female directors on environmental investment has not been done at home and abroad. Therefore, in this paper three common measurement methods for female directors are used to fully verify the impact of female directors on environmental investment.

Taking the listed companies in Shanghai and Shenzhen stock markets in China in 2008-2015 as samples and using the fixed effect method of unbalanced panel data, we mainly study the impact of female directors on the scale of corporate environmental investment. It is found that female directors have a significantly positive impact on corporate environmental investment when at least three female directors appear on the board. This conclusion passes the robustness test. Meanwhile, the following two aspects are considered in this paper: First, enterprises with different types of ownership have different characteristics, and management's awareness of environmental protection is different, and there are some differences in decision-making [26]. Private-owned enterprises pay more attention to the realization of the best interest of their own shareholders and pursue higher economic benefits than state-owned enterprises. State-owned enterprises tend to shoulder more social responsibilities and public expectations [27], and state authorities impose more interventions on state-owned enterprises [28], so the board needs to think more about environmental benefits when making decisions. Second, enterprises with different industry attributes have different scales of environmental investment [29]. Compared with non-heavily-polluting industries, heavily-polluting industries are the major contributors to environmental pollution and therefore are more susceptible to legal punishment and government regulation. Therefore, this paper further analyzes the impact of female directors on corporate environmental investment in enterprises with different types of ownership and industry attributes, and finds that the above-mentioned impact is significant in state-owned enterprises and heavily-polluting industries. The research in this paper enriches theories about gender structure of the board of directors, and finds a great breakthrough for the increasingly concerned environmental issues in China as well.

The innovations of this paper are as follows: First, we empirically test the positive impact of female directors on the scale of corporate environmental investment from the perspective of gender diversity on the board of directors, in order to promote enterprises to better fulfill their social responsibility. At present, research on environmental investment both at home and abroad is mainly embodied in the macro level, focusing on the current situation of environmental investment and its influencing factors [30]. In addition, most of the research on corporate governance and corporate environmental problems focuses on environmental information disclosure [31-33], while there is little literature on corporate environmental investment. Therefore, this paper studies the impact of female directors on environmental investment from a micro perspective. Second, by further categorizing listed companies according to different types of ownership and attributes, we find that there is a significantly positive impact of at least three female directors in state-owned enterprises and heavily-polluting industries 
on corporate environmental investment. In the existing literature, the impact is studied either by classifying in accordance with different types of ownership [34] or only focusing on the status of heavily-polluting industries [35]. Few literatures have tested the impact from these two perspectives in unison. Third, the conclusion drawn in this paper further verifies the importance of critical-mass theory of female directors, proving once again that " 3 " is a fantastic number [36], which is equivalent to verify the conclusion of the original literature at a new dimension, and this theory will be further extended in the future, in order to solve more problems in various fields.

The structure of the paper is as follows: The second part shows theoretical analysis and research hypothesis; the third part presents research design; the fourth part is an empirical test; the fifth part is a research conclusion and policy suggestions.

\section{Theoretical Analysis and Research Hypothesis}

The following theoretical explanations are popular in the existing literature on the impact of female directors on the board's decision on corporate environmental investment. The first is critical-mass theory proposed by Kanter [37], arguing that the performance of the entire group will improve once the number of women reaches a certain size in the group and a relatively gender balance is achieved. Rosener [38] and Shrader et al. [39] find the importance of three female directors in strengthening the work of the board of directors. Through interviewing directors, Kramer et al. [40] find that once at least three female directors appear on the board, they no longer merely represent a "female point of view", so board members will pay attention to female directors' opinions rather than their gender. Through analyzing the board meetings of some listed companies in Israel, Miriam [41] finds that when there are at least three female directors, they perform more actively at the meeting, which verifies the important of critical-mass theory. According to the information asymmetry theory, female directors are easily marginalized and tend to keep silent when the number of female directors on the board is one or two, while female directors prefer to express themselves [36] in the decision-making process when the number of female directors reaches at least three, which finally realizes the information symmetry theory.

The second is social role theory. Social role theory holds that men are personal-oriented (aggressive, ambitious, strong, dominant) and women are public-oriented (loving, helpful, concerned about the well-being of others) [42]. In order to be consistent with the "gender role" [43], female directors tend to behave in ways that meet the expectations of the community. When making decisions, they will take kindness and compassion as the principle. The challenges that enterprises are facing can be better addressed when the board achieves gender diversity [25]. For example, female directors help enterprises understand the needs of stakeholders and address them well [44]. Female directors are more likely to provide some different points of view for the board, such as social charitable donation [16] and community environment [45,46], so as to improve the social image of enterprises. Besides, female care ethics considers that there are moral differences between male and female. Men tend to regard themselves as independent existence, while women regard morality as the responsibility to others and pursue a kind of care ethic that values responsibility and relationship.

The last is group dynamics theory. Group dynamics theory emphasizes how rights are given to group decisions in the context of gender balance [47]. In the group, personal thoughts and behaviors are influenced by others. Byron and Post [48] argue that the presence of both women and men on the board can bring different knowledge, experience and value, which is helpful to improve the quality of business decisions. Female directors take a more active part than male directors because of their cautious and responsible attitude [49]. The more people attending the meeting will make the group decision-making more reliable. As a result, when the number of female directors on the board reaches a certain number, the group decision-making process of the board of directors can be substantially changed. In addition, the typical characteristics of female directors will make group decisions more effective. For example, female directors tend to be risk-averse [50,51]. Therefore, when a certain 
number of women is present, some risky decisions may be stopped and corporate performance will be enhanced.

Based on the above theories, we study the main body of this paper, i.e., corporate environmental investment. First, critical mass theory and group dynamics theory show that female directors play a more prominent role on the board of directors when there are at least three female directors. Second, the social role theory holds that women have the characteristics of caring for others and being very responsible. Therefore, when the board of directors intends to fulfill social responsibility and make decisions on corporate environmental investment, it can get strong support from female directors and thereby enhancing the possibility to approve the decisions. In addition, since female directors are risk-averse, they will pay more attention to the fulfillment of corporate environmental responsibility in order to avoid the risk of legal penalty cost due to environmental pollution and the possible decline of business performance in the long run. Based on a study of 865 listed companies in the United States, Li et al. [52] find that gender diversity on the board has a significantly positive impact on the development of environmental policies. So how is the impact of female directors on environmental investment? Through the above analysis, we predict that female directors have a significantly positive impact on the scale of corporate environmental investment. Therefore, this paper proposes the following hypothesis:

Hypothesis H1. The Blau index is positively correlated with the scale of corporate environmental investment.

Hypothesis H2. The proportion of female directors is positively correlated with the scale of corporate environmental investment.

Hypothesis H3. The critical mass of female directors (at least three) is positively correlated with the size of corporate environmental investment.

\section{Research Design}

\subsection{Sample Selection and Data Sources}

In this paper, the listed companies in Shanghai and Shenzhen stock markets in 2008-2015 are taken as samples. In order to ensure the integrity and reliability of the data, the following samples are excluded: 1 . The samples that have not disclosed their environmental investment for more than three consecutive years; 2 . Financial companies, security companies and insurance companies because of their special industry attributes and operational characteristics; 3. B shares, H shares (Hong Kong-listed stocks) and N shares (New York-listed stocks) enterprises; 4. The samples with missing data, such as financial data, board data and so on. In the end, we obtained 199 sample enterprises and 910 observations in 2008-2015. The distribution of sample enterprises in each year is shown in Table 1. The reason why sample selection begins in 2008 is that listed companies have been gradually disclosing relevant environmental information since the release of Guidelines for Environmental Information Disclosure of Listed Companies by Shanghai Stock Exchange in 2008.

The main sources of data in this paper are: 1 . Most of the financial data and the structure of the board of directors come from CSMAR. A few missing data are obtained by consulting the annual reports of listed companies or through the website of Stock Star and the official website of Money163; 2. Environmental investment data are collected and sorted by hand from independent social responsibility reports, sustainability reports and environmental reports disclosed on Cninfo, the official website of CSRC; 3. Macro-level data come from statistical yearbooks. For example, regional economic development and regional sewage discharge are from China Statistical Yearbook, while financial development is from China Financial Statistical Yearbook; 4 . In order to ensure the integrity of the samples, missing environmental investment data of some enterprises in a few years will be processed with interpolation method through the stata14 command. In order to eliminate the influence of outliers, we use winsorize to process the major continuous variables at $1 \%$ and $99 \%$ 
quantiles in the regression test so as to ensure the authenticity and reliability of the results. Stata14 software is used for empirical analysis.

Table 1. Sample company annual distribution.

\begin{tabular}{ccccccccc}
\hline Year & 2008 & 2009 & $\mathbf{2 0 1 0}$ & $\mathbf{2 0 1 1}$ & $\mathbf{2 0 1 2}$ & $\mathbf{2 0 1 3}$ & $\mathbf{2 0 1 4}$ & $\mathbf{2 0 1 5}$ \\
\hline Number of companies & 26 & 38 & 74 & 112 & 139 & 154 & 168 & 199 \\
\hline
\end{tabular}

\subsection{Variable Design and Definition}

\subsubsection{Dependent Variables}

The dependent variable is the scale of corporate environmental investment Environmental Protection Investment (EPI). After referring to the research on corporate environmental investment by Tang and Li [29], we divide corporate environmental investment into the following seven categories based on the disclosure of actual corporate social responsibility reports: Expenditure on environmental technology research and development and reconstruction, expenditure on environmental facilities and systems and reconstruction, expenditure on pollution control, expenditure on clean production, environmental taxes, expenditure on ecological protection and other environmental investments. In the collection of environmental investment data, we are in strict accordance with this classification method. In this paper, we use the common definition method of studying corporate environmental investment literature to reflect the scale of corporate environmental investment, which is calculated as $\mathrm{EPI}=\frac{\text { Environmental investment }}{\text { Average total assets }}$, where "average total assets" refers to the arithmetic average of the total assets at the beginning of the year and the total assets at the end of the year.

\subsubsection{Independent Variables}

This paper mainly analyzes the impact of female directors on corporate environmental investment. There are many ways in which academics can measure the variable of female directors. In order to comprehensively understand the impact of female directors on corporate environmental investment, several common measurement methods for female directors are used for research and analysis (the proportion of female director (FDP), Blau index (Blau) and critical-mass). In order to prove the validity of critical-mass theory, we set up three comparative variables: Only one female director, only two female directors and three and above female directors, respectively. Table 2 shows selection and definition of explanatory variables.

Table 2. Variable selection and definition.

\begin{tabular}{|c|c|c|c|}
\hline & Variable Name & $\begin{array}{l}\text { Variable } \\
\text { Symbol }\end{array}$ & Variable Description \\
\hline $\begin{array}{l}\text { Dependent } \\
\text { variables }\end{array}$ & $\begin{array}{l}\text { Scale of corporate } \\
\text { environmental investment }\end{array}$ & EPI & Environmental investment/average total assets \\
\hline \multirow{5}{*}{$\begin{array}{l}\text { Independent } \\
\text { variables }\end{array}$} & Blau index & Blau & 1-FDP^2-(1-FDP)^2 \\
\hline & Female director proportion & FDP & Number of female directors/total number of directors \\
\hline & 1 female director & Onlyone & $\begin{array}{l}\text { When there is } 1 \text { female director on the board of directors } \\
\text { the assignment is } 1 \text {. Otherwise, the assignment is } 0 .\end{array}$ \\
\hline & 2 female directors & Onlytwo & $\begin{array}{l}\text { When there are } 2 \text { female directors on the board of } \\
\text { directors the assignment is } 1 \text {. Otherwise, the assignment } \\
\text { is } 0 .\end{array}$ \\
\hline & at least 3 female directors & Leastthree & $\begin{array}{l}\text { When there are at least } 3 \text { female directors on the board } \\
\text { of directors the assignment is } 1 \text {. Otherwise, } \\
\text { the assignment is } 0 .\end{array}$ \\
\hline
\end{tabular}


Table 2. Cont.

\begin{tabular}{|c|c|c|c|c|}
\hline \multicolumn{3}{|c|}{ Variable Name } & $\begin{array}{l}\text { Variable } \\
\text { Symbol }\end{array}$ & \multirow[t]{2}{*}{ Variable Description } \\
\hline \multirow{14}{*}{$\begin{array}{c}\text { Control } \\
\text { variables }\end{array}$} & \multirow{4}{*}{$\begin{array}{l}\text { Financial } \\
\text { variable }\end{array}$} & Asset size & Size & \\
\hline & & $\begin{array}{l}\text { Financial } \\
\text { leverage }\end{array}$ & LEV & Total liabilities/total assets \\
\hline & & $\begin{array}{l}\text { Business } \\
\text { performance }\end{array}$ & ROA & Net profit/total average assets \\
\hline & & $\begin{array}{l}\text { Sustainable } \\
\text { development } \\
\text { capacity }\end{array}$ & SDC & $\begin{array}{l}\text { Ending shareholder equity/beginning } \\
\text { shareholder equity }\end{array}$ \\
\hline & \multirow{6}{*}{$\begin{array}{l}\text { Corporate } \\
\text { governance } \\
\text { variable }\end{array}$} & $\begin{array}{l}\text { Different types of } \\
\text { ownership }\end{array}$ & SOE & $\begin{array}{l}\text { The assignment is } 1 \text { when state-owned. } \\
\text { Otherwise, the assignment is } 0\end{array}$ \\
\hline & & $\begin{array}{l}\text { Ownership } \\
\text { concentration }\end{array}$ & OC & The proportion of the largest shareholder \\
\hline & & $\begin{array}{c}\text { Board } \\
\text { independence }\end{array}$ & BI & The proportion of independent directors \\
\hline & & Board size & BS & The natural logarithm of the number of board members \\
\hline & & $\begin{array}{l}\text { Chairman and } \\
\text { CEO } \\
\text { concurrently }\end{array}$ & CEOdual & $\begin{array}{l}0 \text { The assignment is } 1 \text { when not chairman and CEO } \\
\text { concurrently, while the assignment is } 0 \text { when chairman } \\
\text { and CEO concurrently. }\end{array}$ \\
\hline & & Board ownership & $\mathrm{BO}$ & Directors' equity/total share capital of the enterprise \\
\hline & \multirow[t]{4}{*}{$\begin{array}{l}\text { External } \\
\text { influencing } \\
\text { factors }\end{array}$} & $\begin{array}{l}\text { Local control } \\
\text { intensity }\end{array}$ & $\mathrm{CI}$ & $\begin{array}{l}\text { The assignment of ecologically fragile areas } \\
\text { (According to the document [2008] No. } 92 \text { of Ministry of } \\
\text { Environmental Protection, ecologically fragile areas } \\
\text { include Heilongjiang, Inner Mongolia, Jilin, Liaoning, } \\
\text { Hebei, Shanxi, Shaanxi, Ningxia, Gansu, Qinghai, } \\
\text { Xinjiang, Tibet, Sichuan, Yunnan, Guizhou, Guangxi, } \\
\text { Chongqing, Hubei, Jiangxi and Anhui, a total of } \\
21 \text { provinces (autonomous regions and municipalities } \\
\text { directly under the Central Government)) is } 1 . \\
\text { Otherwise, the assignment is } 0 .\end{array}$ \\
\hline & & $\begin{array}{l}\text { Local sewage } \\
\text { discharge level }\end{array}$ & SDL & Local sewage discharge/national sewage discharge \\
\hline & & $\begin{array}{l}\text { Local economic } \\
\text { development }\end{array}$ & LED & $\begin{array}{l}\text { The natural logarithm of real per GDP in the } \\
\text { headquarter area where the company is located }\end{array}$ \\
\hline & & $\begin{array}{l}\text { Local financial } \\
\text { development }\end{array}$ & LFD & (Deposit + loan amount)/regional GDP \\
\hline
\end{tabular}

\subsubsection{Control Variables}

Draw lessons from the existing research results, this paper selects the variables that have an important impact on the scale of corporate environmental investment as control variables, which are mainly divided into three categories: 1 . Corporate financial variables: Asset size (Size), financial leverage (Leverage, LEV), business performance (Return on Assets, ROA), and sustainable development capacity (SDC); 2. Corporate governance variables: ownership (state-owned Enterprise, SOE), ownership concentration (OC) [53], board independence (BI) [9], board size (BS) [25], chairman and CEO concurrently (CEO dual), and board ownership (BO) [50]; 3. External influence factors of environmental investment: Local control intensity (Control Intensity, CI) [12], local sewage discharge level (SDL), local economic development (LED) and local financial development LFD) [54]. In addition, annual dummy variables are also introduced in this paper to control the impact of annual effects.

The specific definition of the abovementioned variables, explanatory variables and control variables is shown in Table 2. 


\subsection{Model Building}

In order to test the impact of female directors of listed companies on the scale of corporate environmental investment, this paper designs the following empirical regression model:

$$
\begin{aligned}
\text { EPI }= & \beta_{0}+\beta_{1} \mathrm{FB}_{\mathrm{i}}+\beta_{2} \mathrm{LEV}+\beta_{3} \text { Size }+\beta_{4} \mathrm{SDC}+\beta_{5} \mathrm{ROA}+\beta_{6} \mathrm{OC}+\beta_{7} \mathrm{BI}+\beta_{8} \mathrm{BS}+\beta_{9} \mathrm{BO} \\
& +\beta_{10} \mathrm{SDL}+\beta_{11} \mathrm{LED}+\beta_{12} \mathrm{LFD}+\beta_{13} \text { CEOdual }+\beta_{14} \mathrm{CI}+\beta_{15} \mathrm{SOE}+\Sigma \text { Year }+\varepsilon
\end{aligned}
$$

Among which, $\mathrm{FB}_{\mathrm{i}}$ is the participation index of female directors, including 5 variables, i.e., Blau, FDP, Onlyone, Onlytwo, Leastthree.

\section{Empirical Analysis}

\subsection{Descriptive Statistics and Analysis}

The descriptive statistics of all variables are shown in Table 3. The mean and median of EPI are 0.0071 and 0.0020 , respectively, indicating that the average proportion of corporate environmental investment to the total assets is about $0.71 \%$. The vast majority of environmental investment is below the average of the total samples, to a certain extent indicating that there is currently insufficient investment in environmental protection in the sample enterprises [29]. The standard deviation of EPI is large, and the difference between the maximum value and the minimum value is also very large, suggesting that there are prominent individual differences in environmental investment and the scale of environmental investment of the samples is not stable. The mean value of SOE is 0.753 , implying that most of the social responsibility reports on environmental investment disclosure are released by state-owned enterprises. It can be preliminarily found that environmental investment of non-state-owned enterprises needs to be improved. The change in explanatory variable means that the proportion of female directors on the board is still low, and that there are fewer sample enterprises with more than three female directors, suggesting that gender imbalance on the board of enterprises in China and the number of female directors needs to be improved [55].

Panel A and Panel B in Table 4 describe the samples of state-owned enterprises and non-state-owned enterprises, as well as the samples of heavily-polluting (On 14 September 2010, in order to urge listed companies to actively fulfill their environmental responsibilities and satisfy the public's right to know about the environment, Ministry of Environmental Protection promulgated Guidelines for Environmental Information Disclosure of Listed companies (Draft), in which heavily-polluting industries include thermal power, steel, cement, electrolytic aluminum, coal, metallurgy, chemical engineering, petrochemical engineering, building materials, papermaking, brewing, pharmacy, fermentation, textile, leather and mining industries. See Classification Management List of Listed Companies on Environmental Inspection (MEP. Doc. [2008] No. 373) that) and non-heavily-polluting industries, respectively. By contrast, we find that the observed value of the samples of state-owned enterprises and heavily-polluting industries is higher than that of non-state-owned enterprises and non-heavily-polluting industries, indicating that non-state-owned enterprises and non-heavily-polluting industries in China need to pay more attention to environmental investment [29]. In terms of ownership, the lower standard deviation of state-owned enterprises shows that the scale of environmental investment in state-owned enterprises is relatively stable. The mean of environmental investment of non-state-owned enterprises is much larger than the median, implying that the majority of non-state-owned enterprises have smaller investment scale. From the perspective of industry attributes, heavily-polluting industries pay more attention to environmental investment. The average size of their environmental investment is much larger than that of non-heavily-polluting industries, and also greater than the overall average of 0.0071 , which is consistent with the conclusion of Tang et al. [29]. 


\subsection{Correlation Test and Analysis}

We tested the correlation of the variables involved in regression and the results are shown in Table 5. From the perspective of correlation matrix, there is a positive correlation between female directors and corporate environmental investment when the number of female directors on the board is three or at least two. The coefficient increases, while there is no significant correlation, preliminarily indicating that female directors have an impact on environmental investment. In addition, most of the independent variables and control variables are significantly correlated with each other at the level of $10 \%$ or above, but the correlation coefficients between the major variables are relatively low, suggesting that there is no serious multiple colinearity in the model.

Table 3. Descriptive statistics.

\begin{tabular}{ccccccc}
\hline Variable & Obs & Mean & Std.Dev. & Median & Min & Max \\
\hline EPI & 910 & 0.0071 & 0.0190 & 0.0020 & 0 & 0.285 \\
Only one & 910 & 0.357 & 0.479 & 0 & 0 & 1 \\
Only two & 910 & 0.197 & 0.398 & 0 & 0 & 1 \\
At least three & 910 & 0.0989 & 0.299 & 0 & 0 & 1 \\
Blau & 910 & 0.176 & 0.153 & 0.1975 & 0 & 0.500 \\
FDP & 910 & 0.115 & 0.116 & 0.1111 & 0 & 0.667 \\
Lev & 910 & 0.508 & 0.194 & 0.5248 & 0.0415 & 0.952 \\
Size & 910 & 23.34 & 1.627 & 23.1856 & -0.0077 & 27.32 \\
ROA & 910 & 0.0472 & 0.0626 & 0.0349 & -0.249 & 0.477 \\
SDC & 910 & 1.140 & 0.301 & 1.0728 & 0.160 & 4.465 \\
OC & 910 & 0.429 & 0.167 & 0.4310 & 0 & 0.885 \\
BI & 910 & 0.372 & 0.0633 & 0.3333 & 0.231 & 0.714 \\
BS & 910 & 2.257 & 0.206 & 2.1972 & 1.609 & 2.890 \\
BO & 910 & 2.552 & 9.043 & 0.0010 & 0 & 57.52 \\
SDL & 910 & 0.0498 & 0.0355 & 0.0374 & 0.0007 & 0.126 \\
LED & 910 & 10.88 & 0.458 & 10.9825 & 9.196 & 11.59 \\
LFD & 910 & 1.712 & 0.795 & 1.5364 & 0.154 & 3.793 \\
CEO dual & 910 & 0.903 & 0.296 & 1 & 0 & 1 \\
CI & 910 & 0.301 & 0.459 & 0 & 0 & 1 \\
SOE & 910 & 0.753 & 0.432 & 1 & 0 & 1 \\
\hline
\end{tabular}

Table 4. Descriptive statistics according to different levels.

\begin{tabular}{|c|c|c|c|c|c|c|}
\hline \multicolumn{7}{|c|}{ Panel A Property Rights Group } \\
\hline \multirow{2}{*}{ Variable } & \multicolumn{3}{|c|}{ State-Owned Enterprises } & \multicolumn{3}{|c|}{ Non-State-Owned Enterprises } \\
\hline & Obs & Mean & Std.Dev. & Obs & Mean & Std.Dev. \\
\hline EPI & 685 & 0.0060 & 0.0156 & 225 & 0.0105 & 0.0266 \\
\hline Only one & 685 & 0.352 & 0.478 & 225 & 0.373 & 0.485 \\
\hline Only two & 685 & 0.190 & 0.392 & 225 & 0.218 & 0.414 \\
\hline At least three & 685 & 0.0993 & 0.299 & 225 & 0.0978 & 0.298 \\
\hline Blau & 685 & 0.170 & 0.152 & 225 & 0.194 & 0.154 \\
\hline FDP & 685 & 0.110 & 0.113 & 225 & 0.130 & 0.125 \\
\hline Lev & 685 & 0.536 & 0.188 & 225 & 0.425 & 0.187 \\
\hline Size & 685 & 23.63 & 1.705 & 225 & 22.48 & 0.941 \\
\hline ROA & 685 & 0.0416 & 0.0587 & 225 & 0.0644 & 0.0705 \\
\hline SDC & 685 & 1.121 & 0.253 & 225 & 1.197 & 0.410 \\
\hline OC & 685 & 0.451 & 0.159 & 225 & 0.363 & 0.172 \\
\hline $\mathrm{BI}$ & 685 & 0.373 & 0.0658 & 225 & 0.367 & 0.0547 \\
\hline BS & 685 & 2.281 & 0.206 & 225 & 2.185 & 0.187 \\
\hline $\mathrm{BO}$ & 685 & 0.112 & 1.713 & 225 & 9.980 & 15.79 \\
\hline SDL & 685 & 0.0463 & 0.0347 & 225 & 0.0605 & 0.0361 \\
\hline LED & 685 & 10.88 & 0.478 & 225 & 10.89 & 0.390 \\
\hline LFD & 685 & 1.637 & 0.764 & 225 & 1.940 & 0.846 \\
\hline CEO dual & 685 & 0.930 & 0.255 & 225 & 0.822 & 0.383 \\
\hline $\mathrm{CI}$ & 685 & 0.336 & 0.473 & 225 & 0.196 & 0.398 \\
\hline
\end{tabular}


Table 4. Cont.

\begin{tabular}{ccccccc}
\hline \multicolumn{7}{c}{ Panel B Industry Attributes Group } \\
\hline \multirow{2}{*}{ Variable } & Heavily-Polluting Industries & Non-Heavily-Polluting Industries \\
\cline { 2 - 6 } & Obs & Mean & Std.Dev. & Obs & Mean & Std.Dev. \\
\hline EPI & 569 & 0.0084 & 0.0186 & 341 & 0.0050 & 0.0197 \\
Only one & 569 & 0.376 & 0.485 & 341 & 0.326 & 0.469 \\
Only two & 569 & 0.160 & 0.367 & 341 & 0.258 & 0.438 \\
At least three & 569 & 0.0721 & 0.259 & 341 & 0.144 & 0.351 \\
Blau & 569 & 0.156 & 0.146 & 341 & 0.210 & 0.158 \\
FDP & 569 & 0.0985 & 0.104 & 341 & 0.142 & 0.130 \\
Lev & 569 & 0.546 & 0.201 & 341 & 0.445 & 0.163 \\
Size & 569 & 23.47 & 1.783 & 341 & 23.14 & 1.305 \\
ROA & 569 & 0.0404 & 0.0637 & 341 & 0.0586 & 0.0590 \\
SDC & 569 & 1.122 & 0.282 & 341 & 1.170 & 0.329 \\
OC & 569 & 0.446 & 0.164 & 341 & 0.400 & 0.167 \\
BI & 569 & 0.374 & 0.0618 & 341 & 0.369 & 0.0656 \\
BS & 569 & 9.815 & 2.110 & 341 & 9.692 & 2.197 \\
BO & 569 & 2.931 & 9.942 & 341 & 1.918 & 7.269 \\
SDL & 569 & 0.0490 & 0.0353 & 341 & 0.0512 & 0.0359 \\
LED & 569 & 10.81 & 0.463 & 341 & 11.00 & 0.423 \\
LFD & 569 & 1.672 & 0.794 & 341 & 1.780 & 0.794 \\
CEO dual & 569 & 0.923 & 0.267 & 341 & 0.871 & 0.336 \\
CI & 569 & 0.327 & 0.469 & 341 & 0.258 & 0.438 \\
\hline
\end{tabular}

\subsection{Multiple Regression Test and Analysis}

Taking the listed companies from 2008-2015 as the sample, this paper finally obtains a non-balanced panel data. When choosing regression method, we used Hausman Test and found that the fixed effect method should be used for the static panel. Therefore, the regression results of the fixed effect model are used in this paper. The results of multiple regression test in this paper are shown in Table 6. It should be noted that, in order to better avoid the impact of endogeneity on the model regression results, this paper considers the lagged one time interval for all the independent variables in the model. The regression results in column 1 show that the regression results are positive but not significant when female directors are measured by the index of gender diversity i.e., Blau index, so that Hypothesis H1 is false. This may be due to the fact that a larger Blau index represents a more balanced gender distribution, which will not serve to further enhance the board's activity [41] and therefore cannot affect the decision-making of corporate environmental investment. The regression results in column 2 show that there is no significantly positive impact of the proportion of female directors on corporate environmental investment, so that $\mathrm{H}_{2}$ is false. The regression results in columns 3,4 , and 5 show a negative impact of only one female director and only two female directors on corporate environmental investment, but there is not sufficient evidence. Therefore, we consider that one or two female directors have no impact on the scale of corporate environmental investment. There is a significantly positive impact (significant at the level of $5 \%$ ) of at least three female directors (critical-mass) on corporate environmental investment, so that $\mathrm{H} 3$ is true. We can explain the negative correlation coefficient from the following aspects. First, since there are only one or two female directors, male directors occupy an overwhelming proportion and become "dominant" on the board. In this case, female directors are often only regarded as a symbol of gender diversity. The board will not consider or even seek advice from female directors when making investment decisions. Meanwhile, due to the disproportionation, female directors fear that their opinions are not supported in making decisions. Therefore, female directors tend to pretend to hide their points of view so as to be in accordance with male directors. These will not be conducive to exert unique advantages of female directors, and play no decisive role in promoting environmental investment. When at least three female directors are present on the board, they feel more comfortable, supported and will be freer to ask questions and actively participate in the decision-making process. This fully embodies the magic power of the critical mass of female directors. The presence of at least three female directors is likely to have a significant impact on corporate social responsibility, which is consistent with the conclusion of Miriam [41] on female directors. 
Table 5. Correlation test.

\begin{tabular}{|c|c|c|c|c|c|c|c|c|c|c|c|c|c|c|c|c|c|c|c|}
\hline & EPI & Blau & FDP & Only One & $\begin{array}{l}\text { Only } \\
\text { Two }\end{array}$ & $\begin{array}{c}\text { At Least } \\
\text { Three }\end{array}$ & LEV & Size & SDC & OC & BI & BS & во & SDL & LED & LFD & CEOdual & CI & SOE \\
\hline EPI & 1.000 & & & & & & & & & & & & & & & & & & \\
\hline $\begin{array}{l}\text { Blau } \\
\text { FDP }\end{array}$ & $\begin{array}{l}-0.046 \\
-0.038\end{array}$ & $\begin{array}{c}1.000 \\
0.973^{* * *}\end{array}$ & 1.000 & & & & & & & & & & & & & & & & \\
\hline Only one & $-0.066^{*}$ & $0.065 *$ & $\begin{array}{l}1.000 \\
-0.045\end{array}$ & 1.000 & & & & & & & & & & & & & & & \\
\hline Only two & 0.008 & $0.528 * * *$ & $0.451^{* * *}$ & $-0.391 * * *$ & 1.000 & & & & & & & & & & & & & & \\
\hline At least three & 0.057 & $0.262^{* * *}$ & $0.327^{* * *}$ & $-0.174^{* * *}$ & -0.044 & 1.000 & & & & & & & & & & & & & \\
\hline LEV & $0.063 *$ & -0.073 * & -0.06 & $-0.065 *$ & -0.033 & $-0.097 * * *$ & 1.000 & & & & & & & & & & & & \\
\hline Size & -0.096 ** & $-0.193 * * *$ & $-0.172 * * *$ & -0.038 & $-0.111 * * *$ & $-0.125 * * *$ & $0.476^{* * *}$ & 1.000 & & & & & & & & & & & \\
\hline SDC & -0.025 & -0.027 & -0.026 & -0.048 & 0.008 & 0.009 & $-0.124 * * *$ & -0.018 & 1.000 & & & & & & & & & & \\
\hline OC & $-0.063 *$ & $-0.134 * * *$ & $-0.132 * * * *$ & & $-0.115 * * *$ & $-0.149 * * *$ & $0.106^{* * *}$ & $0.378 * * *$ & $-0.079 * *$ & 1.000 & & & & & & & & & \\
\hline BI & -0.022 & $-0.160 * * *$ & $-0.147 * * *$ & -0.042 & -0.077 ** & -0.047 & -0.005 & $0.220 * * *$ & -0.057 & $0.166^{* * *}$ & 1.000 & & & & & & & & \\
\hline BS & 0.058 & -0.056 & -0.053 & -0.023 & -0.033 & $0.132 * * *$ & 0.049 & $0.134 * * *$ & $0.080 * *$ & 0.007 & $-0.306 * * *$ & 1.000 & & & & & & & \\
\hline BO & 0.035 & $0.174^{* * *}$ & $0.205^{* * * *}$ & 0.013 & 0.013 & 0.031 & $-0.207 * * *$ & $-0.244 * * *$ & 0.041 & $-0.230 * * *$ & -0.033 & $-0.111 * * *$ & 1.000 & & & & & & \\
\hline SDL & $-0.072 *$ & $0.105^{* * *}$ & $0.083 * *$ & $0.167 * *$ & 0.006 & 0.003 & -0.086 ** & $-0.175 * * *$ & $\begin{array}{l}0.058 \\
0.058\end{array}$ & $-0.213^{* * *}$ & $\begin{array}{l}-0.051 \\
-0.051\end{array}$ & $-0.144 * * *$ & $0.161^{* * *}$ & 1.000 & & & & & \\
\hline LED & $-0.208 * * *$ & 0.01 & 0.013 & $0.075 * *$ & -0.057 & 0.001 & $-0.127^{* * *}$ & $0.160^{* * *}$ & $-0.106 * * *$ & $0.139 * * *$ & $0.070 *$ & $-0.105 * * *$ & 0.026 & 0.071 * & 1.000 & & & & \\
\hline LFD & $-0.123 * * *$ & $0.128^{* * *}$ & $0.114^{* * *}$ & $0.206 * * *$ & -0.009 & 0.025 & $-0.098 * * *$ & -0.076 ** & 0.045 & $-0.182 * * *$ & -0.011 & $-0.114 * * *$ & $0.221^{* * *}$ & $0.874 * * *$ & $0.159^{* * *}$ & 1.000 & & & \\
\hline CEO dual & -0.011 & 0.011 & 0.016 & -0.032 & 0.025 & -0.044 & $0.107^{* * *}$ & $0.063 *$ & -0.054 & $0.073 *$ & $-0.129 * * *$ & $0.107^{* * *}$ & -0.014 & $-0.126 * * *$ & $-0.100 * * *$ & $-0.093 * *$ & 1.000 & & \\
\hline CI & $0.122 * * *$ & -0.002 & 0.013 & $-0.128^{* * *}$ & 0.022 & 0.022 & $0.125^{* * *}$ & -0.011 & 0.055 & $-0.107^{* * *}$ & -0.016 & $0.205^{* * *}$ & -0.083 ** & $-0.437 * * *$ & $-0.689 * * *$ & $-0.425 * * *$ & $0.122 * * *$ & 1.000 & \\
\hline SOE & $-0.147 * * *$ & -0.033 & -0.033 & -0.024 & -0.017 & 0.001 & $0.257^{* * *}$ & $0.347^{* * *}$ & $-0.098 * * *$ & $0.216^{* * *}$ & 0.035 & $0.193^{* * *}$ & $-0.456^{* * *}$ & $-0.174 * * *$ & 0.022 & $-0.167^{* * *}$ & $0.102 * * *$ & $0.129 * * *$ & 1.000 \\
\hline
\end{tabular}


As for control variables, we can see from the regression analysis that: among financial variables, there is a significantly negative correlation between LEV, Size and SDC and the scale of corporate environmental investment (significant level is 10\%,5\%,5\%, respectively). Among corporate governance variables, there is a significantly positive correlation between OC and BS and the scale of corporate environmental investment (significant level is $10 \%$ and $1 \%$, respectively). Among external factors, there is a significant correlation between SDL and LFD and corporate environmental investment. Among them, SDL is significantly negatively correlated with the corporate environmental investment at the $10 \%$ level, indicating that the cities with more serious pollution may be negligent in supervising enterprises, and environmental awareness of these enterprises may not be strong; LFD is significantly positive correlated with corporate environmental investment at the $1 \%$ level, suggesting that with higher financial development, local enterprises may be more likely to raise funds, such as to buy environmentally-friendly and energy-saving equipment.

Table 6. Multiple regression results.

\begin{tabular}{|c|c|c|c|c|c|}
\hline & (1) & (2) & (3) & (4) & (5) \\
\hline Blau & $\begin{array}{c}0.0019 \\
(0.0048)\end{array}$ & & & & \\
\hline FDP & & $\begin{array}{c}0.0045 \\
(0.0061)\end{array}$ & & & \\
\hline Only one & & & $\begin{array}{l}-0.0006 \\
(0.0012)\end{array}$ & & \\
\hline Only two & & & & $\begin{array}{l}-0.0007 \\
(0.0014)\end{array}$ & \\
\hline At least three & & & & & $\begin{array}{c}0.0053^{* *} \\
(0.0024)\end{array}$ \\
\hline LEV & $\begin{array}{c}-0.0121 * \\
(0.0068)\end{array}$ & $\begin{array}{c}-0.0122 * \\
(0.0068)\end{array}$ & $\begin{array}{c}-0.0121 * \\
(0.0068)\end{array}$ & $\begin{array}{c}-0.0120 * \\
(0.0068)\end{array}$ & $\begin{array}{l}-0.0111 \\
(0.0068)\end{array}$ \\
\hline Size & $\begin{array}{c}-0.0043^{* *} \\
(0.0020)\end{array}$ & $\begin{array}{c}-0.0043^{* *} \\
(0.0020)\end{array}$ & $\begin{array}{c}-0.0043^{* *} \\
(0.0020)\end{array}$ & $\begin{array}{c}-0.0043^{* *} \\
(0.0020)\end{array}$ & $\begin{array}{c}-0.0047^{* *} \\
(0.0020)\end{array}$ \\
\hline SDC & $\begin{array}{c}-0.0049^{* *} \\
(0.0020)\end{array}$ & $\begin{array}{c}-0.0048^{* *} \\
(0.0020)\end{array}$ & $\begin{array}{c}-0.0050^{* *} \\
(0.0020)\end{array}$ & $\begin{array}{c}-0.0051 \text { ** } \\
(0.0020)\end{array}$ & $\begin{array}{c}-0.0048 \\
(0.0020)\end{array}$ \\
\hline ROA & $\begin{array}{l}-0.0095 \\
(0.0120)\end{array}$ & $\begin{array}{l}-0.0095 \\
(0.0120)\end{array}$ & $\begin{array}{l}-0.0093 \\
(0.0120)\end{array}$ & $\begin{array}{l}-0.0099 \\
(0.0120)\end{array}$ & $\begin{array}{l}-0.0096 \\
(0.0120)\end{array}$ \\
\hline OC & $\begin{array}{l}0.0170 * \\
(0.0093)\end{array}$ & $\begin{array}{l}0.0170^{*} \\
(0.0093)\end{array}$ & $\begin{array}{l}0.0166^{*} \\
(0.0093)\end{array}$ & $\begin{array}{l}0.0169^{*} \\
(0.0093)\end{array}$ & $\begin{array}{l}0.0181 * \\
(0.0093)\end{array}$ \\
\hline BI & $\begin{array}{c}0.0030 \\
(0.0148)\end{array}$ & $\begin{array}{c}0.0032 \\
(0.0148)\end{array}$ & $\begin{array}{c}0.0027 \\
(0.0148)\end{array}$ & $\begin{array}{c}0.0026 \\
(0.0148)\end{array}$ & $\begin{array}{c}0.0023 \\
(0.0148)\end{array}$ \\
\hline BS & $\begin{array}{c}0.0041 \\
(0.0058)\end{array}$ & $\begin{array}{c}0.0042 \\
(0.0058)\end{array}$ & $\begin{array}{c}0.0040 \\
(0.0058)\end{array}$ & $\begin{array}{c}0.0037 \\
(0.0058)\end{array}$ & $\begin{array}{c}0.0034 \\
(0.0058)\end{array}$ \\
\hline BO & $\begin{array}{c}0.0012 * * * \\
(0.0002)\end{array}$ & $\begin{array}{c}0.0012 * * * \\
(0.0002)\end{array}$ & $\begin{array}{c}0.0012 * * * \\
(0.0002)\end{array}$ & $\begin{array}{c}0.0012 * * * \\
(0.0002)\end{array}$ & $\begin{array}{c}0.0012 * * * \\
(0.0002)\end{array}$ \\
\hline SDL & $\begin{array}{c}-0.1050 * \\
(0.0561)\end{array}$ & $\begin{array}{c}-0.1050 * \\
(0.0561)\end{array}$ & $\begin{array}{c}-0.1050 * \\
(0.0561)\end{array}$ & $\begin{array}{c}-0.1060 * \\
(0.0561)\end{array}$ & $\begin{array}{c}-0.0943 * \\
(0.0561)\end{array}$ \\
\hline LED & $\begin{array}{l}-0.0043 \\
(0.0114)\end{array}$ & $\begin{array}{l}-0.0042 \\
(0.0114)\end{array}$ & $\begin{array}{l}-0.0043 \\
(0.0114)\end{array}$ & $\begin{array}{l}-0.0055 \\
(0.0115)\end{array}$ & $\begin{array}{l}-0.0029 \\
(0.0114)\end{array}$ \\
\hline LFD & $\begin{array}{c}0.0253 * * * \\
(0.0069)\end{array}$ & $\begin{array}{c}0.0252^{* * *} \\
(0.0069)\end{array}$ & $\begin{array}{c}0.0257^{* * *} \\
(0.0069)\end{array}$ & $\begin{array}{c}0.0254^{* * *} \\
(0.0069)\end{array}$ & $\begin{array}{c}0.0263^{* * *} \\
(0.0069)\end{array}$ \\
\hline CEO dual & $\begin{array}{l}-0.0015 \\
(0.0027)\end{array}$ & $\begin{array}{l}-0.0015 \\
(0.0027)\end{array}$ & $\begin{array}{l}-0.0016 \\
(0.0027)\end{array}$ & $\begin{array}{l}-0.0014 \\
(0.0027)\end{array}$ & $\begin{array}{l}-0.0008 \\
(0.0027)\end{array}$ \\
\hline CI & $\begin{array}{l}-0.0009 \\
(0.0081)\end{array}$ & $\begin{array}{l}-0.0007 \\
(0.0081)\end{array}$ & $\begin{array}{c}-0.0006 \\
(0.0082)\end{array}$ & $\begin{array}{l}-0.0005 \\
(0.0082)\end{array}$ & $\begin{array}{l}-0.0010 \\
(0.0081)\end{array}$ \\
\hline SOE & $\begin{array}{c}0.0002 \\
(0.0124)\end{array}$ & $\begin{array}{l}-0.0000 \\
(0.0124)\end{array}$ & $\begin{array}{c}0.0002 \\
(0.0124)\end{array}$ & $\begin{array}{c}0.0002 \\
(0.0124)\end{array}$ & $\begin{array}{c}0.0002 \\
(0.0124)\end{array}$ \\
\hline $\begin{array}{l}\text { Year } \\
\text { _cons }\end{array}$ & $\begin{array}{c}\text { control } \\
0.1090 \\
(0.1320)\end{array}$ & $\begin{array}{c}\text { control } \\
0.1070 \\
(0.1320)\end{array}$ & $\begin{array}{c}\text { control } \\
0.1090 \\
(0.1320)\end{array}$ & $\begin{array}{c}\text { control } \\
0.1240 \\
(0.1330)\end{array}$ & $\begin{array}{c}\text { control } \\
0.0990 \\
(0.1310)\end{array}$ \\
\hline$N$ & 711 & 711 & 711 & 711 & 711 \\
\hline$R^{2}$ & 0.1340 & 0.1350 & 0.1340 & 0.1340 & 0.1420 \\
\hline
\end{tabular}

Note: The brackets for the corresponding standard deviation; dependent variables and independent variables were $1 \%$ level of the winsorize processing; regression of all independent variables and control variables are lagging behind; $* * *$, and ${ }^{* * *}$ indicate significance levels of $10 \%, 5 \%$ and $1 \%$, respectively; standard errors in parentheses. 


\subsection{Further Analysis}

In order to further study the impact of female directors on the scale of corporate environmental investment, and to provide new policy guidance for Chinese enterprises to better fulfill their social environmental responsibility, we divided all samples into four groups according to different types of ownership and industry attributes. Here, we only seleted the proportion of female directors, Blau index and critical mass to measure independent variables.

First, through the regression analysis of the observations of state-owned enterprises and private-owned enterprises in the basic model, we found that there is a big difference between state-owned enterprises and private-owned enterprises. As shown in Table 7, of the three measurement indexes of female directors, the presence of at least three female directors on the board of state-owned enterprises has a significantly positive impact (at the level of 5\%) on corporate environmental investment, whereas the three measurement indexes of female directors are positive but not significant in private enterprises. This may be mainly due to the nature of state-owned enterprises. In state-owned enterprises, directors are usually appointed administratively and state-owned assets can be the backup. Therefore, state-owned enterprises are not necessary to bear the excessive costs of fulfilling environmental responsibility and can better comply with national environmental policies, which may be conducive to job promotion [56]. Coupled with female inherent characteristics of caring and tendencies to avoid risks, the impact of female directors in state-owned enterprises on environmental investment is significant.

Second, through the regression analysis of the observations of heavily-polluting industries and those of non-heavily-polluting industries in the basic model (see Table 8 for the regression results ), we find that the presence of at least three female directors in heavily-polluting industries has a significantly positive impact on environmental investment at the $5 \%$ level. Besides, the influence coefficient of at least three female directors is much larger than the overall influence coefficient. However, there is no significant correlation among non-heavily-polluting enterprises. The reason may be that due to the increasingly prominent environmental problems in China mainly caused by heavily-polluting industries, on the one hand, the state and relevant departments of environmental protection will step up the supervision and punishment on heavily-polluting enterprises; on the other hand, "gender role" of female directors are risk-averse, so they actively perform their social responsibility towards others. Therefore, compared with those in non-heavily-polluting industries, female directors in heavily-polluting industries have a positive impact of on environmental investment.

Table 7. Regression results under different property rights.

\begin{tabular}{|c|c|c|c|c|c|c|}
\hline & \multicolumn{3}{|c|}{ State-Owned Enterprises } & \multicolumn{3}{|c|}{ Non-State-Owned Enterprises } \\
\hline & (1) & (2) & (3) & (1) & (2) & (3) \\
\hline Blau & $\begin{array}{c}0.0024 \\
(0.0050)\end{array}$ & & & $\begin{array}{c}0.0165 \\
(0.0190)\end{array}$ & & \\
\hline FDP & & $\begin{array}{c}0.0079 \\
(0.0067)\end{array}$ & & & $\begin{array}{c}0.0251 \\
(0.0260)\end{array}$ & \\
\hline At least three & & & $\begin{array}{l}0.0044^{* *} \\
(0.0021)\end{array}$ & & & $\begin{array}{c}0.0141 \\
(0.0138)\end{array}$ \\
\hline LEV & $\begin{array}{c}-0.0277^{* * *} \\
(0.0069)\end{array}$ & $\begin{array}{c}-0.0276^{* * *} \\
(0.0069)\end{array}$ & $\begin{array}{c}-0.0265^{* * *} \\
(0.0069)\end{array}$ & $\begin{array}{c}0.0107 \\
(0.0184)\end{array}$ & $\begin{array}{c}0.0109 \\
(0.0184)\end{array}$ & $\begin{array}{c}0.0042 \\
(0.0185)\end{array}$ \\
\hline Size & $\begin{array}{l}-0.0005 \\
(0.0019)\end{array}$ & $\begin{array}{l}-0.0006 \\
(0.0019)\end{array}$ & $\begin{array}{l}-0.0007 \\
(0.0019)\end{array}$ & $\begin{array}{c}-0.0175^{* *} \\
(0.0069)\end{array}$ & $\begin{array}{c}-0.0176^{* *} \\
(0.0069)\end{array}$ & $\begin{array}{c}-0.0181 \text { ** } \\
(0.0070)\end{array}$ \\
\hline SDC & $\begin{array}{c}-0.0042 * \\
(0.0021)\end{array}$ & $\begin{array}{l}-0.0040 * \\
(0.0021)\end{array}$ & $\begin{array}{c}-0.0043^{* *} \\
(0.0021)\end{array}$ & $\begin{array}{l}-0.0016 \\
(0.0047)\end{array}$ & $\begin{array}{l}-0.0016 \\
(0.0047)\end{array}$ & $\begin{array}{l}-0.0021 \\
(0.0047)\end{array}$ \\
\hline ROA & $\begin{array}{l}-0.0225^{*} \\
(0.0120)\end{array}$ & $\begin{array}{l}-0.0226^{*} \\
(0.0119)\end{array}$ & $\begin{array}{l}-0.0226^{*} \\
(0.0119)\end{array}$ & $\begin{array}{c}-0.0734 * \\
(0.0409)\end{array}$ & $\begin{array}{c}-0.0769 * \\
(0.0412)\end{array}$ & $\begin{array}{c}-0.0733 \text { * } \\
(0.0408)\end{array}$ \\
\hline
\end{tabular}


Table 7. Cont.

\begin{tabular}{ccccccc}
\hline & \multicolumn{2}{c}{ State-Owned Enterprises } & \multicolumn{2}{c}{ Non-State-Owned Enterprises } \\
\hline & $\mathbf{( 1 )}$ & $\mathbf{( 2 )}$ & $\mathbf{( 3 )}$ & $\mathbf{( 1 )}$ & $\mathbf{( 2 )}$ & $\mathbf{( 3 )}$ \\
\hline OC & 0.0113 & 0.0118 & 0.0120 & 0.0382 & 0.0397 & 0.0350 \\
& $(0.0087)$ & $(0.0087)$ & $(0.0086)$ & $(0.0342)$ & $(0.0343)$ & $(0.0330)$ \\
BI & -0.0044 & -0.0041 & -0.0057 & 0.0073 & 0.0106 & 0.0035 \\
& $(0.0145)$ & $(0.0145)$ & $(0.0144)$ & $(0.0406)$ & $(0.0410)$ & $(0.0402)$ \\
BS & -0.0044 & -0.0045 & -0.0052 & $0.0256^{*}$ & $0.0261 *$ & 0.0227 \\
& $(0.0059)$ & $(0.0059)$ & $(0.0059)$ & $(0.0148)$ & $(0.0148)$ & $(0.0150)$ \\
BO & $0.0015 * * *$ & $0.0015 * * *$ & $0.0016^{* * *}$ & 0.0007 & 0.0007 & 0.0007 \\
& $(0.0002)$ & $(0.0002)$ & $(0.0002)$ & $(0.0005)$ & $(0.0005)$ & $(0.0005)$ \\
SDL & -0.0431 & -0.0414 & -0.0264 & -0.1120 & -0.1020 & -0.1090 \\
& $(0.0585)$ & $(0.0584)$ & $(0.0587)$ & $(0.1630)$ & $(0.1630)$ & $(0.1620)$ \\
LED & -0.0133 & -0.0128 & -0.0108 & $0.1020 *$ & 0.0971 & 0.0781 \\
& $(0.0105)$ & $(0.0105)$ & $(0.0105)$ & $(0.0593)$ & $(0.0595)$ & $(0.0637)$ \\
LFD & $0.0205 * * *$ & $0.0206 * * *$ & $0.0214 * * *$ & $0.0676^{* *}$ & $0.0649 * *$ & $0.0630 * *$ \\
& $(0.0066)$ & $(0.0066)$ & $(0.0066)$ & $(0.0260)$ & $(0.0260)$ & $(0.0261)$ \\
CEO dual & -0.0007 & -0.0006 & 0.0002 & -0.0078 & -0.0077 & -0.0084 \\
& $(0.0026)$ & $(0.0026)$ & $(0.0027)$ & $(0.0071)$ & $(0.0071)$ & $(0.0070)$ \\
CI & 0.0060 & 0.0072 & 0.0057 & -0.0006 & -0.0006 & 0.0009 \\
& $(0.0100)$ & $(0.0100)$ & $(0.0099)$ & $(0.0155)$ & $(0.0154)$ & $(0.0151)$ \\
Year & control & control & control & control & control & control \\
cons & 0.1550 & 0.1500 & 0.1310 & -0.9100 & -0.8530 & -0.6120 \\
& $(0.1210)$ & $(0.1210)$ & $(0.1210)$ & $(0.7170)$ & $(0.7200)$ & $(0.7780)$ \\
$\boldsymbol{N}$ & 542 & 542 & 542 & 167 & 167 & 167 \\
$\boldsymbol{R}^{2}$ & 0.2270 & 0.2290 & 0.2340 & 0.2750 & 0.2770 & 0.2770 \\
\hline
\end{tabular}

Note: The brackets for the corresponding standard deviation; dependent variables and independent variables were $1 \%$ level of the winsorize processing; regression of all independent variables and control variables are lagging behind; $* * *$, and ${ }^{* * *}$ indicate significance levels of $10 \%, 5 \%$ and $1 \%$, respectively; standard errors in parentheses.

Table 8. Regression results under different industry attributes.

\begin{tabular}{|c|c|c|c|c|c|c|}
\hline & \multicolumn{3}{|c|}{ Heavily-Polluting Industries } & \multicolumn{3}{|c|}{ Non-Heavily-Polluting Industries } \\
\hline & (1) & (2) & (3) & (1) & (2) & (3) \\
\hline Blau & $\begin{array}{c}0.0048 \\
(0.0060)\end{array}$ & & & $\begin{array}{l}0.0147 * \\
(0.0081)\end{array}$ & & \\
\hline FDP & & $\begin{array}{c}0.0038 \\
(0.0082)\end{array}$ & & & $\begin{array}{c}0.0157 \\
(0.0106)\end{array}$ & \\
\hline At least three & & & $\begin{array}{c}0.0094^{* *} \\
(0.0042)\end{array}$ & & & $\begin{array}{c}-0.0004 \\
(0.0031)\end{array}$ \\
\hline LEV & $\begin{array}{l}-0.0099 \\
(0.0093)\end{array}$ & $\begin{array}{l}-0.0098 \\
(0.0093)\end{array}$ & $\begin{array}{l}-0.0085 \\
(0.0092)\end{array}$ & $\begin{array}{l}-0.0131 \\
(0.0108)\end{array}$ & $\begin{array}{l}-0.0128 \\
(0.0108)\end{array}$ & $\begin{array}{l}-0.0135 \\
(0.0110)\end{array}$ \\
\hline Size & $\begin{array}{c}-0.0054^{* *} \\
(0.0027)\end{array}$ & $\begin{array}{c}-0.0054^{* *} \\
(0.0027)\end{array}$ & $\begin{array}{c}-0.0061^{* *} \\
(0.0026)\end{array}$ & $\begin{array}{c}0.0001 \\
(0.0033)\end{array}$ & $\begin{array}{l}-0.0002 \\
(0.0033)\end{array}$ & $\begin{array}{l}-0.0005 \\
(0.0034)\end{array}$ \\
\hline SDC & $\begin{array}{c}-0.0047^{*} \\
(0.0028)\end{array}$ & $\begin{array}{c}-0.0047^{*} \\
(0.0028)\end{array}$ & $\begin{array}{l}-0.0044 \\
(0.0028)\end{array}$ & $\begin{array}{c}-0.0071^{* *} \\
(0.0029)\end{array}$ & $\begin{array}{c}-0.0068^{* *} \\
(0.0029)\end{array}$ & $\begin{array}{c}-0.0066^{* *} \\
(0.0030)\end{array}$ \\
\hline ROA & $\begin{array}{l}0.0248 \text { * } \\
(0.0146)\end{array}$ & $\begin{array}{l}0.0248^{*} \\
(0.0146)\end{array}$ & $\begin{array}{l}0.0255^{*} \\
(0.0145)\end{array}$ & $\begin{array}{c}0.0280 \\
(0.0226)\end{array}$ & $\begin{array}{c}0.0274 \\
(0.0227)\end{array}$ & $\begin{array}{c}0.0241 \\
(0.0233)\end{array}$ \\
\hline OC & $\begin{array}{l}0.0250 * \\
(0.0139)\end{array}$ & $\begin{array}{l}0.0252 * \\
(0.0139)\end{array}$ & $\begin{array}{l}0.0253 * \\
(0.0138)\end{array}$ & $\begin{array}{c}0.0090 \\
(0.0146)\end{array}$ & $\begin{array}{c}0.0075 \\
(0.0145)\end{array}$ & $\begin{array}{c}0.0041 \\
(0.0145)\end{array}$ \\
\hline BI & $\begin{array}{c}0.0020 \\
(0.0208)\end{array}$ & $\begin{array}{c}0.0021 \\
(0.0209)\end{array}$ & $\begin{array}{c}0.0016 \\
(0.0207)\end{array}$ & $\begin{array}{c}0.0067 \\
(0.0254)\end{array}$ & $\begin{array}{c}0.0048 \\
(0.0254)\end{array}$ & $\begin{array}{c}0.0010 \\
(0.0255)\end{array}$ \\
\hline BS & $\begin{array}{c}0.0014 \\
(0.0083)\end{array}$ & $\begin{array}{c}0.0015 \\
(0.0083)\end{array}$ & $\begin{array}{c}0.0020 \\
(0.0083)\end{array}$ & $\begin{array}{c}0.0093 \\
(0.0084)\end{array}$ & $\begin{array}{c}0.0094 \\
(0.0084)\end{array}$ & $\begin{array}{c}0.0106 \\
(0.0085)\end{array}$ \\
\hline BO & $\begin{array}{c}0.0017^{* * *} \\
(0.0003)\end{array}$ & $\begin{array}{c}0.0017^{* * *} \\
(0.0003)\end{array}$ & $\begin{array}{c}0.0017^{* * *} \\
(0.0003)\end{array}$ & $\begin{array}{c}0.0000 \\
(0.0003)\end{array}$ & $\begin{array}{c}0.0000 \\
(0.0003)\end{array}$ & $\begin{array}{c}0.0001 \\
(0.0003)\end{array}$ \\
\hline
\end{tabular}


Table 8. Cont.

\begin{tabular}{|c|c|c|c|c|c|c|}
\hline & \multicolumn{3}{|c|}{ Heavily-Polluting Industries } & \multicolumn{3}{|c|}{ Non-Heavily-Polluting Industries } \\
\hline & (1) & (2) & (3) & (1) & (2) & (3) \\
\hline SDL & $\begin{array}{l}-0.0456 \\
(0.0849)\end{array}$ & $\begin{array}{l}-0.0436 \\
(0.0850)\end{array}$ & $\begin{array}{l}-0.0238 \\
(0.0844)\end{array}$ & $\begin{array}{c}-0.1650 * * \\
(0.0793)\end{array}$ & $\begin{array}{c}-0.1590 \text { ** } \\
(0.0794)\end{array}$ & $\begin{array}{c}-0.1540 \text { * } \\
(0.0798)\end{array}$ \\
\hline LED & $\begin{array}{c}0.0049 \\
(0.0154)\end{array}$ & $\begin{array}{c}0.0044 \\
(0.0155)\end{array}$ & $\begin{array}{c}0.0071 \\
(0.0153)\end{array}$ & $\begin{array}{l}-0.0201 \\
(0.0191)\end{array}$ & $\begin{array}{l}-0.0194 \\
(0.0192)\end{array}$ & $\begin{array}{l}-0.0229 \\
(0.0192)\end{array}$ \\
\hline LFD & $\begin{array}{c}0.0286^{* * *} \\
(0.0098)\end{array}$ & $\begin{array}{c}0.0285^{* * *} \\
(0.0098)\end{array}$ & $\begin{array}{c}0.0282 * * * \\
(0.0097)\end{array}$ & $\begin{array}{c}0.0127 \\
(0.0115)\end{array}$ & $\begin{array}{c}0.0136 \\
(0.0115)\end{array}$ & $\begin{array}{c}0.0158 \\
(0.0115)\end{array}$ \\
\hline CEO dual & $\begin{array}{l}-0.0009 \\
(0.0034)\end{array}$ & $\begin{array}{l}-0.0009 \\
(0.0034)\end{array}$ & $\begin{array}{c}0.0001 \\
(0.0034)\end{array}$ & $\begin{array}{c}0.0070 \\
(0.0051)\end{array}$ & $\begin{array}{c}0.0070 \\
(0.0051)\end{array}$ & $\begin{array}{c}0.0070 \\
(0.0051)\end{array}$ \\
\hline CI & $\begin{array}{l}-0.0009 \\
(0.0128)\end{array}$ & $\begin{array}{l}-0.0012 \\
(0.0128)\end{array}$ & $\begin{array}{l}-0.0024 \\
(0.0126)\end{array}$ & & & \\
\hline SOE & & & & $\begin{array}{c}0.0003 \\
(0.0100)\end{array}$ & $\begin{array}{c}-0.0004 \\
(0.0100)\end{array}$ & $\begin{array}{c}0.0001 \\
(0.0101)\end{array}$ \\
\hline Year & control & control & control & control & control & control \\
\hline _cons & $\begin{array}{c}0.0264 \\
(0.1800)\end{array}$ & $\begin{array}{c}0.0327 \\
(0.1800)\end{array}$ & $\begin{array}{c}0.0147 \\
(0.1780)\end{array}$ & $\begin{array}{c}0.1860 \\
(0.2120)\end{array}$ & $\begin{array}{c}0.1860 \\
(0.2130)\end{array}$ & $\begin{array}{c}0.2310 \\
(0.2120)\end{array}$ \\
\hline$N$ & 421 & 421 & 421 & 260 & 260 & 260 \\
\hline$R^{2}$ & 0.1940 & 0.1930 & 0.2050 & 0.1350 & 0.1300 & 0.1190 \\
\hline
\end{tabular}

Note: The brackets for the corresponding standard deviation; dependent variables and independent variables were $1 \%$ level of the winsorize processing; regression of all independent variables and control variables are lagging behind; ${ }^{* * *}$, and ${ }^{* * *}$ indicate significance levels of $10 \%, 5 \%$ and $1 \%$, respectively; standard errors in parentheses.

\subsection{Robustness Test and Analysis}

In order to test the robustness of the conclusion, this paper regresses the scale of environmental investment with different measurement methods and tests the impact of female directors on the scale of environmental investment of listed companies. The dependent variables are respectively measured through the natural logarithm of environmental amount invested (denoted as Lnei) and the result of the environmental amount invested dividing by the total operating income of enterprises (denoted as Ei1) and then regression of the fixed effect of the model is carried out. The regression results are shown in Table 9. From the regression results in Table 9, it can be concluded that when corporate environmental investment is measured in different ways, the presence of at least three female directors on the board has a significantly positive impact on corporate environmental investment and passes the significance test at $10 \%$ and $1 \%$ level. To sum up, we can conclude that the regression results of robustness test do not change the above conclusion. The results further support the hypotheses in this paper, so we can conclude that the conclusion in this paper is reliable.

Table 9. Robustness test.

\begin{tabular}{|c|c|c|c|c|c|c|}
\hline & \multicolumn{3}{|c|}{ Lnei } & \multicolumn{3}{|c|}{ Ei1 } \\
\hline & (1) & (2) & (3) & (1) & (2) & (3) \\
\hline Blau & $\begin{array}{l}-0.5530 \\
(0.6460)\end{array}$ & & & $\begin{array}{c}0.0025 \\
(0.0092)\end{array}$ & & \\
\hline FDP & & $\begin{array}{c}-0.8580 \\
(0.8320)\end{array}$ & & & $\begin{array}{c}0.0043 \\
(0.0119)\end{array}$ & \\
\hline At least three & & & $\begin{array}{l}0.5580 * \\
(0.3290)\end{array}$ & & & $\begin{array}{c}0.0159^{* * *} \\
(0.0047)\end{array}$ \\
\hline LEV & $\begin{array}{c}-4.6690 * * * \\
(0.9230)\end{array}$ & $\begin{array}{c}-4.6620 * * * \\
(0.9230)\end{array}$ & $\begin{array}{c}-4.5680^{* * *} \\
(0.9230)\end{array}$ & $\begin{array}{c}-0.0431 * * * \\
(0.0132)\end{array}$ & $\begin{array}{c}-0.0431 * * * \\
(0.0132)\end{array}$ & $\begin{array}{c}-0.0400^{* * * *} \\
(0.0130)\end{array}$ \\
\hline Size & $\begin{array}{l}-0.0567 \\
(0.2660)\end{array}$ & $\begin{array}{l}-0.0546 \\
(0.2660)\end{array}$ & $\begin{array}{l}-0.1040 \\
(0.2670)\end{array}$ & $\begin{array}{l}-0.0033 \\
(0.0038)\end{array}$ & $\begin{array}{l}-0.0033 \\
(0.0038)\end{array}$ & $\begin{array}{l}-0.0044 \\
(0.0038)\end{array}$ \\
\hline SDC & $\begin{array}{c}0.0252 \\
(0.2680)\end{array}$ & $\begin{array}{c}0.0186 \\
(0.2680)\end{array}$ & $\begin{array}{c}0.0690 \\
(0.2660)\end{array}$ & $\begin{array}{l}-0.0018 \\
(0.0038)\end{array}$ & $\begin{array}{l}-0.0018 \\
(0.0038)\end{array}$ & $\begin{array}{l}-0.0014 \\
(0.0038)\end{array}$ \\
\hline
\end{tabular}


Table 9. Cont.

\begin{tabular}{|c|c|c|c|c|c|c|}
\hline & \multicolumn{3}{|c|}{ Lnei } & \multicolumn{3}{|c|}{ Ei1 } \\
\hline & (1) & (2) & (3) & (1) & (2) & (3) \\
\hline ROA & $\begin{array}{l}-2.2430 \\
(1.6380)\end{array}$ & $\begin{array}{l}-2.2340 \\
(1.6370)\end{array}$ & $\begin{array}{l}-2.2240 \\
(1.6350)\end{array}$ & $\begin{array}{l}-0.0024 \\
(0.0233)\end{array}$ & $\begin{array}{l}-0.0024 \\
(0.0233)\end{array}$ & $\begin{array}{l}-0.0025 \\
(0.0231)\end{array}$ \\
\hline OC & $\begin{array}{l}-2.1320 * \\
(1.2680)\end{array}$ & $\begin{array}{c}-2.1150 * \\
(1.2660)\end{array}$ & $\begin{array}{l}-1.9460 \\
(1.2660)\end{array}$ & $\begin{array}{l}-0.0140 \\
(0.0181)\end{array}$ & $\begin{array}{l}-0.0140 \\
(0.0180)\end{array}$ & $\begin{array}{l}-0.0105 \\
(0.0179)\end{array}$ \\
\hline BI & $\begin{array}{c}2.8690 \\
(2.0180)\end{array}$ & $\begin{array}{c}2.8630 \\
(2.0180)\end{array}$ & $\begin{array}{c}2.8650 \\
(2.0140)\end{array}$ & $\begin{array}{l}-0.0158 \\
(0.0288)\end{array}$ & $\begin{array}{l}-0.0158 \\
(0.0288)\end{array}$ & $\begin{array}{l}-0.0178 \\
(0.0284)\end{array}$ \\
\hline BS & $\begin{array}{l}-0.1900 \\
(0.7880)\end{array}$ & $\begin{array}{l}-0.1940 \\
(0.7880)\end{array}$ & $\begin{array}{l}-0.2150 \\
(0.7860)\end{array}$ & $\begin{array}{c}-0.0268 \text { ** } \\
(0.0112)\end{array}$ & $\begin{array}{c}-0.0268 \text { ** } \\
(0.0112)\end{array}$ & $\begin{aligned}-0.0288^{* * * *} & (0.0111)\end{aligned}$ \\
\hline BO & $\begin{array}{l}-0.0193 \\
(0.0288)\end{array}$ & $\begin{array}{l}-0.0191 \\
(0.0288)\end{array}$ & $\begin{array}{l}-0.0184 \\
(0.0288)\end{array}$ & $\begin{array}{l}-0.0001 \\
(0.0004)\end{array}$ & $\begin{array}{l}-0.0001 \\
(0.0004)\end{array}$ & $\begin{array}{l}-0.0000 \\
(0.0004)\end{array}$ \\
\hline SDL & $\begin{array}{c}-14.5800 * \\
(7.6370)\end{array}$ & $\begin{array}{c}-14.6800 * \\
(7.6350)\end{array}$ & $\begin{array}{c}-13.4500 * \\
(7.6510)\end{array}$ & $\begin{array}{l}-0.0979 \\
(0.1090)\end{array}$ & $\begin{array}{l}-0.0974 \\
(0.1090)\end{array}$ & $\begin{array}{l}-0.0651 \\
(0.1080)\end{array}$ \\
\hline LED & $\begin{array}{l}-2.1500 \\
(1.5530)\end{array}$ & $\begin{array}{l}-2.1490 \\
(1.5510)\end{array}$ & $\begin{array}{l}-1.8580 \\
(1.5500)\end{array}$ & $\begin{array}{c}-0.0482 \text { ** } \\
(0.0221)\end{array}$ & $\begin{array}{c}-0.0482 * * \\
(0.0221)\end{array}$ & $\begin{array}{c}-0.0432 * * \\
(0.0219)\end{array}$ \\
\hline LFD & $\begin{array}{c}0.0084 \\
(0.9400)\end{array}$ & $\begin{array}{c}0.0185 \\
(0.9400)\end{array}$ & $\begin{array}{c}0.0841 \\
(0.9390)\end{array}$ & $\begin{array}{c}0.0049 \\
(0.0134)\end{array}$ & $\begin{array}{c}0.0049 \\
(0.0134)\end{array}$ & $\begin{array}{c}0.0078 \\
(0.0133)\end{array}$ \\
\hline CEO dual & $\begin{array}{c}-0.8390 * * \\
(0.3620)\end{array}$ & $\begin{array}{c}-0.8430 * * \\
(0.3620)\end{array}$ & $\begin{array}{c}-0.7660 * * \\
(0.3640)\end{array}$ & $\begin{array}{c}-0.0152^{* * *} \\
(0.0052)\end{array}$ & $\begin{array}{c}-0.0152^{* * *} \\
(0.0052)\end{array}$ & $\begin{array}{c}-0.0130^{* *} \\
(0.0052)\end{array}$ \\
\hline CI & $\begin{array}{l}-0.4720 \\
(1.1080)\end{array}$ & $\begin{array}{l}-0.5130 \\
(1.1070)\end{array}$ & $\begin{array}{l}-0.5010 \\
(1.1050)\end{array}$ & $\begin{array}{l}-0.0045 \\
(0.0158)\end{array}$ & $\begin{array}{l}-0.0043 \\
(0.0158)\end{array}$ & $\begin{array}{l}-0.0048 \\
(0.0156)\end{array}$ \\
\hline SOE & $\begin{array}{c}0.3330 \\
(1.6900)\end{array}$ & $\begin{array}{c}0.3660 \\
(1.6900)\end{array}$ & $\begin{array}{c}0.3340 \\
(1.6870)\end{array}$ & $\begin{array}{c}0.0033 \\
(0.0241)\end{array}$ & $\begin{array}{c}0.0031 \\
(0.0241)\end{array}$ & $\begin{array}{c}0.0034 \\
(0.0238)\end{array}$ \\
\hline Year & control & control & control & control & control & control \\
\hline _cons & $\begin{array}{c}36.8900 * * \\
(17.9500)\end{array}$ & $\begin{array}{c}36.8100 * * \\
(17.9300)\end{array}$ & $\begin{array}{l}34.2400 * \\
(17.8900)\end{array}$ & $\begin{array}{c}0.7230^{* * *} \\
(0.2560)\end{array}$ & $\begin{array}{c}0.7230^{* * *} \\
(0.2560)\end{array}$ & $\begin{array}{c}0.6870^{* * *} \\
(0.2530)\end{array}$ \\
\hline$N$ & 711 & 711 & 711 & 711 & 711 & 711 \\
\hline$R^{2}$ & 0.1160 & 0.1160 & 0.1190 & 0.0880 & 0.0880 & 0.1080 \\
\hline
\end{tabular}

Note: The brackets for the corresponding standard deviation; dependent variables and independent variables were $1 \%$ level of the winsorize processing; regression of all independent variables and control variables are lagging behind; $* * *$, and ${ }^{* * *}$ indicate significance levels of $10 \%, 5 \%$ and $1 \%$, respectively; standard errors in parentheses.

\section{Conclusions and Suggestions}

Females play an increasingly important role in the development of modern economy. It deserves attention whether female directors has an impact on the decision-making behavior of listed companies in environmental investment? Based on the sample of listed companies in stock markets of Shanghai and Shenzhen in 2008-2015, this paper empirically tests the impact of the number of female directors on environmental investment, and further analyzes the impact of the number of female directors on the decision-making of environmental investment of enterprises with different types of ownership and industry attributes. The results show that the presence of at least three female directors plays a significant role in promoting environmental investment. However, when the number of female directors is too small (only one or two), their presence has no significant impact on the decision-making of environmental investment. That is to say, the role of female directors is not obvious. When female directors are also measured by the proportion or Blau index, the impact of female directors on environmental investment is not significant. This further proves the value of critical mass theory in the decision-making of environmental investment by the board of directors. Due to the special nature of state-owned enterprises, the presence of at least three female directors has a significantly positive impact on environmental investment when compared with non-state-owned enterprises. Likewise, compared with non-heavily-polluting industries, the above-mentioned impact is still significant in heavily-polluting industries in which listed companies are major contributors to pollution.

The following policy suggestions are obtained from the results in this paper: (1) Given the significantly positive impact of a certain number of (critical-mass) female directors on corporate 
environmental investment, enterprises should, in the course of selecting their directors in the future, employ a certain number of female directors based on their own operating conditions, in order to give full play to the gender advantages of female directors and actively shoulder social environmental responsibility; (2) Due to the special nature of state-owned enterprises, the presence of at least three female directors on the board has a significant impact on the scale of environmental investment. Therefore, the relevant departments should advocate a reasonable proportion of gender structure on the board so that state-owned enterprises can better fulfill their social environmental responsibility, and set an example for non-state-owned enterprises. For non-state-owned enterprises, they should first increase their awareness of environmental protection investment. Second, they should actively utilize the positive influence of female directors on corporate environmental investment; (3) Heavily-polluting industries should take an active responsibility for social environment and be responsible for their behavior. Meanwhile, heavily-polluting industries may consider starting from the structure of the board of directors, hiring an appropriate number of female directors, actively supporting relevant environmental decision-making and evading legal punishment, in order to improve the market recognition and establish a good corporate image. Although non-heavily polluting industries are not major contributors to environmental pollution, "environmental protection is everyone's responsibility". Therefore, non-heavily polluting industries should also hire an appropriate number of female directors to step up environmental investment and conscientiously fulfill their environmental investment obligations.

Acknowledgments: We are grateful to the suggestions of two anonymous reviewers and financial support of National Social Science Fund (Project No. 17BGL080) and the Fundamental Research Funds for the Central Universities (Project No. CDJKXB13006).

Author Contributions: Feng Wei revised the manuscript, Binyan Ding organized and performed the data analyses, and interpreted data, and Yu Kong approved the final version.

Conflicts of Interest: The authors declare no conflict of interest.

\section{References}

1. Wang, M.; Huang, Y. China's environmental pollution and economic growth. China Econ. Q. 2015, 14, 557-578. (In Chinese)

2. Yungho, C.; Wu, M.F. Environmental efficiency evaluation in China: Application of 'undesirable' data envelopment analysis. Polish J. Environ. Stud. 2010, 19, 1159-1169.

3. Shen, H.P.; Xie, Y.; Chen, Z.R. Environmental Protection, Corporate social responsibility and its market response-Case study based on the environmental pollution incident of Zijin Mining Group Co. China Ind. Econ. 2012, 1, 141-151. (In Chinese)

4. Mohamed, E.H.A.; Guglielno, M.G.; Christophe, R.; Sova, R.; Sova, A. Environmental regulation and competitiveness: Evidence from Romania. Ecol. Econ. 2012, 81, 130-139.

5. Yang, S.; Ye, H.; Zhu, Q. Do peer firms affect firm corporate social responsibility? Sustainability 2017, 9, 1967. [CrossRef]

6. Hyun, E.; Yang, D.; Jung, H.; Hong, K. Women on boards and corporate social responsibility. Sustainability 2016, 8, 300. [CrossRef]

7. Tang, G.P.; Li, L.H.; Wu, D.J. Environmental regulation, industry attributes and corporate environmental investment. Account. Res. 2013, 6, 83-89. (In Chinese)

8. Yang, J.M.; Wang, L.G. A study of efficiency of China's environmental protection investment. Contemp. Financ. Econ. 2009, 9, 20-25.

9. Uwuigbe, U.; Ajibolade, S.O. Effects of corporate governance on corporate social and environmental disclosure among listed firms in Nigeria. Eur. J. Bus. Soc. Sci. 2013, 2, 76-92.

10. Huang, J.; Zhou, C.N. Empirical research on the impact of ownership structure and management behavior on the environmental disclosure: Evidence from heavy polluting industries listed in shanghai stock exchange. China Soft Sci. 2012, 1, 133-143. (In Chinese)

11. Ren, G.Q. Research on corporate environmental protection investment behavior based on corporate governance. J. Zhengzhou Univ. (Philos. Soc. Sci. Ed.) 2017, 50, 66-71. (In Chinese) 
12. Li, H.; Lou, W.; Tian, M.F. Corporate environmental investment, environmental regulation and cost of equity capital: Evidence from heavily-polluting industries listed in Shanghai and Shenzhen Stock Exchange. J. Audit Econ. 2016, 2, 71-80. (In Chinese)

13. Torchia, M.; Calabrò, A.; Huse, M. Women directors on corporate boards: From tokenism to critical mass. J. Bus. Ethics 2011, 102, 299-317. [CrossRef]

14. Terjesen, S.; Aguilera, R.V.; Lorenz, R. Legislating a woman's seat on the board: Institutional factors driving gender quotas for boards of directors. J. Bus. Ethics 2015, 128, 233-251. [CrossRef]

15. Zhou, Z.J. Do female directors matter to audit efforts? J. Shanxi Univ. Financ. Econ. 2014, 36, $101-111$. (In Chinese)

16. Marx, J.D. Women and human services giving. Soc. Work 2000, 45, 27-38. [CrossRef] [PubMed]

17. Zhou, Z.J. Do female directors affect corporate philanthropy? Empirical research based on listed companies in China. J. Shanghai Univ. Financ. Econ. 2014, 16, 78-85. (In Chinese)

18. Zhou, X.; Meng, Q.L.; Liu, X.H. Research on influence of female directors upon corporate social responsibility: Taking charitable donation as example. J. Beijing Technol. Bus. Univ. (Soc. Sci.) 2016, 31, 72-80. (In Chinese)

19. Liu, Y.; Wei, Z.B.; Xie, F.X. Do women directors improve firm performance in China? J. Financ. 2014, 28, 169-184. [CrossRef]

20. Nguyen, T.; Locke, S.; Reddy, K. Does boardroom gender diversity matter? Evidence from a transitional economy. Int. Rev. Econ. Financ. 2015, 37, 184-202. [CrossRef]

21. Hu, Q.; Zhou, D. A study of the Influence of women-board membership on the company performance: Based on the data of 1042 listed companies in China. J. Manag. 2016, 29, 31-37. (In Chinese)

22. Zhang, J.Q.; Zhu, H.; Ding, H.B. Board composition and corporate social responsibility: An empirical investigation in the Post Sarbanes-Oxley Era. J. Bus. Ethics 2013, 114, 381-392. [CrossRef]

23. Rao, K.; Tilt, C. Board composition and corporate social responsibility: The role of diversity, gender, strategy and decision making. J. Bus. Ethics 2016, 138, 327-347. [CrossRef]

24. Nekhili, M.; Nagati, H.; Chtioui, T.; Nekhili, A. Gender-diverse board and the relevance of voluntary CSR reporting. Int. Rev. Financ. Anal. 2017, 50, 81-100. [CrossRef]

25. Jizi, M. The influence of board composition on sustainable development disclosure. Bus. Strategy Environ. 2017, 26, 640-655. [CrossRef]

26. Li, H.; Wang, R.G.; Xu, N.N. Research on the relationship between management capability and corporate environmental investment-Based on the perspective of moderating effect of market competition and nature of property right. East China Econ. Manag. 2017, 31, 136-143. (In Chinese)

27. Yin, K.G.; Wang, Y.Y.; Liu, X.Q. Nature of property rights, managerial ownership and social responsibility information disclosure-Evidence from Chinese listed companies. Res. Econ. Manag. 2014, 9, 114-120. (In Chinese)

28. Shleifer, A.; Vishny, R.W. Politicians and Firms. Q. J. Econ. 1994, 109, 995-1025. [CrossRef]

29. Tang, G.P.; Li, L.H. Structure and distribution characteristics of corporate environmental investment: Empirical evidence from A-Share Listed Companies. J. Audit Econ. 2013, 28, 94-103. (In Chinese)

30. Lin, A.M.; Zhang, Y. A research on the current situation of environmental investment in A-share listed companies in China: Data on social responsibility report and financial report from 2009 to 2015. J. Nanjing Audit Univ. 2016, 13, 60-69. (In Chinese)

31. Bi, Q.; Peng, Y.; Zuo, Y.Y. Environment information disclosure system, corporate governance and environment information disclosure. Account. Res. 2012, 7, 39-47. (In Chinese)

32. Lewis, B.W.; Walls, J.L.; Dowell, G.W.S. Difference in degrees: CEO characteristics and firm environmental disclosure. Strateg. Manag. J. 2014, 35, 712-722. [CrossRef]

33. Zhang, G.Q.; Xiao, H. Characteristics of senior management and corporate environmental disclosure: An empirical study based on institutional theory. J. Xiamen Univ. (Arts Soc. Sci.) 2016, 4, 84-95. (In Chinese)

34. Ye, C.G.; Wang, Z.; Wu, J.F.; Li, H. External governance, environmental information disclosure and the cost of equity financing. Nankai Bus. Rev. 2015, 18, 85-96. (In Chinese)

35. Zheng, R.J. A study on the quality and determinants of environmental information disclosure in Chinese heavily polluting industry. Bus. Manag. J. 2013, 35, 35-46. (In Chinese)

36. Konrad, A.M.; Kramer, V.; Erkut, S. Critical mass: The impact of three or more women on corporate boards. Organ. Dyn. 2008, 37, 145-164. [CrossRef]

37. Kanter, R.M. Men and Women of the Corporation; Basic Books: New York, NY, USA, 1977. 
38. Rosener, J.B. America's Competitive Secret: Using Women as a Management Strategy; Oxford University Press: New York, NY, USA, 1995.

39. Shrader, C.B.; Blackburn, V.B.; Iles, P. Women in management and firm financial performance: An exploratory study. J. Manag. Issues 1997, 9, 355-372.

40. Kramer, V.W.; Konrad, A.M.; Erkut, S. Critical Mass on Corporate Boards: Why Three or More Women Enhance Governance. Wellesley Center for Women Working Paper. 2006. Available online: https: / www.wcwonline.org/Research-Action-Report-Fall/Winter-2006/critical-mass-on-corporateboards-why-three-or-more-women-enhance-governance591 (accessed on 29 November 2017).

41. Miriam, S.Z. Gender and board activeness: The role of a critical mass. J. Financ. Quant. Anal. 2015, 52, 751-780.

42. Eagly, A.H.; Johannesen-Schmidt, M.C. The leadership styles of women and men. J. Soc. Issues 2001, 57, 781-797. [CrossRef]

43. Lv, Y.; Wang, Z.; An, S.M. A literature review of theoretical foundation and empirical study of the effect of women directors on corporate social responsibility. Foreign Econ. Manag. 2014, 36, 14-22. (In Chinese)

44. Bear, S.; Rahman, N.; Post, C. The impact of board diversity and gender composition on corporate social responsibility and firm reputation. J. Bus. Ethics 2010, 97, 207-221. [CrossRef]

45. Campbell, K.; Minguez-Vera, A. Gender diversity in the boardroom and firm financial performance. J. Bus. Ethics 2008, 83, 435-451. [CrossRef]

46. Hillman, A.; Dalziel, T. Boards of directors and firm performance: Integrating agency and resource dependence perspectives. Acad. Manag. Rev. 2003, 28, 383-396.

47. Woolley, A.W.; Chabris, C.F.; Pentland, A.; Hashmi, N.; Malone, T.W. Evidence for a collective intelligence factor in the performance of human groups. Science 2010, 330, 686-688. [CrossRef] [PubMed]

48. Byron, K.; Post, C. Women on boards of directors and corporate social performance: A Meta-Analysis. Corpor. Gov. Int. Rev. 2016, 24, 428-442. [CrossRef]

49. Adams, R.B.; Ferreira, D. Women in the boardroom and their impact on governance and performance. Soc. Sci. Electron. Publ. 2008, 94, 291-309. [CrossRef]

50. Bristy, H.J. Do Female Directors Matter? The Nexus between CSR and Financial. Masters' Thesis, Queensland University of Technology, Brisbane City, Australia, 2016.

51. Zhu, J.G.; Ye, K.T.; Yan, D. Risk-avoidance of women directors and firm investment-From the perspective of financial crisis. Financ. Trade Econ. 2012, 4, 50-58. (In Chinese)

52. Li, J.; Zhao, F.; Chen, S.; Jiang, W.; Liu, T.; Shi, S. Gender diversity on boards and firms' environmental policy. Bus. Strategy Environ. 2016, 26, 306-315. [CrossRef]

53. Hollindale, J.; Kent, P.; Routledge, J.; Chapple, L. Women on Boards and Greenhouse Gas Emission Disclosures. Available online: http:/ / onlinelibrary.wiley.com/doi/10.1111/acfi.12258/epdf (accessed on 29 November 2017).

54. Li, Y.X.; Chen, K.J.; Liu, L.; Zhang, M. External governance environment, industry regulation and over-investment. J. Manag. Sci. 2013, 26, 14-25. (In Chinese)

55. Kang, W.Z. A research on gender imbalance of senior positions in China's listed companies. J. South China Norm. Univ. (Soc. Sci. Ed.) 2014, 2, 88-94. (In Chinese)

56. Zhu, W.L.; Deng, L. Can female executives promote corporate social responsibility?_Evidence form listed firms in China. China Econ. Stud. 2017, 4, 119-135. (In Chinese)

(c) 2017 by the authors. Licensee MDPI, Basel, Switzerland. This article is an open access article distributed under the terms and conditions of the Creative Commons Attribution (CC BY) license (http:/ / creativecommons.org/licenses/by/4.0/). 